\title{
Habitat/sex differences in time at cleaning stations and ectoparasite loads in a Caribbean reef fish
}

\author{
Paul C. Sikkel ${ }^{1,2, *}$, Claire A. Fuller ${ }^{2}$, Wayne Hunte ${ }^{1}$ \\ ${ }^{1}$ Bellairs Research Institute of McGill University, St. James, Barbados, West Indies \\ ${ }^{2}$ Department of Biology, Blackburn Hall 334, Murray State University, Murray, Kentucky 42071-0009, USA
}

\begin{abstract}
We compared time spent at cleaning stations and ectoparasite loads for adult and subadult yellowtail damselfish Microspathodon chrysurus on nearshore fringing reefs in Barbados. In a preliminary study on 2 reefs in summer 1997, both time spent at cleaning stations and frequency of chafing were inversely correlated with distance from shore. A subsequent study in spring 1998 of fish at the shore- and seaward ends of 8 reefs revealed a strong sex by habitat association, with males predominating at the seaward end and females predominating at the shore end. Females and combined fish at the shore end of reefs had access to fewer cleaners but spent more time visiting cleaners than males and combined fish at the seaward end of reefs. Chafing showed the same relative difference but was not significant. Ectoparasites included gnathiid isopod larvae, parasitic copepods, and dactylogyrid monogeneans. Total crustacean loads, but not monogenean loads, increased with body size. With the effects of body size statistically removed, crustacean loads were significantly higher in females and fish at the shore end of reefs. Monogeneans showed a similar but marginally non-significant trend. These data indicate an association between ectoparasite loads and amount of time spent at cleaners, and thus appear consistent with adaptive, mutualistic hypotheses of client-cleaner interactions. However, the causal relationships between them, habitat, and sex remain to be determined.
\end{abstract}

KEY WORDS: Pomacentridae - Coral reef fish - Ectoparasites - Cleaning symbiosis - Caribbean Copepoda $\cdot$ Monogenea $\cdot$ Gnathiidae

\section{INTRODUCTION}

Cleaning is one of the most conspicuous activities on tropical reefs and has attracted the attention of behavioral, marine, and fish ecologists for over 5 decades (reviewed by Poulin 1993, Poulin \& Grutter 1996). Cleaners are small fish or invertebrates that either specialize in removing parasites, mucus, and damaged tissue from other fish or that do so opportunistically, usually as juveniles (e.g. Itzkowitz 1979, Johnson \& Ruben 1988). Cleaners are often site-attached and the sites they occupy on reefs are known as cleaning stations (e.g. Losey 1974).

Cleaners clearly benefit from removing invertebrate ectoparasites and tissue from the host fish (e.g. Losey

\footnotetext{
•E-mail: paul.sikkel@murraystate.edu
}

1974, Gorlick 1984, Grutter 1996a), and their removal of parasites and damaged tissue may also provide some benefits to the host. However, whether there is a net benefit to host fish remains controversial (Losey 1974, 1987, Poulin 1993, Grutter 1996b). This is because: (1) the amount of parasites or damaged tissue removed by cleaners has been highly variable among studies, and is often negligible (Youngbluth 1968, Losey 1974, Gorlick et al. 1987, Grutter 1996b); (2) laboratory studies have failed to show a consistent effect of parasites on responses of client fish to cleaners (Losey 1979); and (3) cleaners are site-attached, and client fish may therefore incur costs as a result of time away from other activities, risk of predation (Trivers 1971) and aggression from other fishes near the cleaning station (Arnal \& Côté 1998).

Adaptive hypotheses, from the client's perspective, predict that the amount of time fish spend at cleaning 
stations should be proportional to the net benefits they receive from cleaning (Poulin 1993, Grutter \& Poulin 1998). Fish with higher external parasite loads or with wounds should therefore spend more time at cleaning stations than less parasitized or uninjured fish. Foster (1985) observed that injured fish spent more time at cleaning stations when their injuries were fresh. Field tests of the prediction with respect to parasite load have primarily used interspecific comparisons, comparing average parasite loads of each species with time spent at cleaning stations (Poulin 1993, Grutter 1995a). While more highly parasitized species tend to spend more time with cleaners, this relationship appears to be confounded by phylogenetic differences (Grutter \& Poulin 1998). One study (Grutter 1995a) also compared cleaning rates among size classes within 1 species and found a positive relationship between size class, time inspected by cleaners, and average parasite loads.

Many coral reef fishes occupy more than 1 habitat, and a few studies have shown spatial and temporal variation in ectoparasite loads and compositions within tropical marine species (Yeo \& Spieler 1980, Grutter 1994,1998 ). An alternative approach may therefore be to compare parasite loads and cleaning among habitats, within species. Potential difficulties with this approach are that (1) highly mobile species frequently move among habitats; (2) most site-attached species are small and have few parasites and/or rarely visit cleaners; and (3) the availability of cleaners and hence the cost of visiting them could also vary among habitats.

The yellowtail damselfish Microspathodon chrysurus is a large (up to $20 \mathrm{~cm}$ TL [total length]) pomacentrid. Like many confamilials, it is territorial year round and occurs in a variety of sub-habitats on coral reefs (Itzkowitz 1977, Waldner \& Robertson 1980). While females travel up to $100 \mathrm{~m}$ from their territory to spawn, spawning is limited to a maximum of 2 h every 3 d during the 3 wk spawning cycle (P. Sikkel \& S. Herzlieb unpubl, data). Thus, they spend over $95 \%$ of their time in or near the territory. During a study of the reproductive ecology of this species, we noticed that fish spent a high but variable amount of time visiting cleaning stations, usually within or near their territory. We thus began a study to examine the relationship between habitat, cleaning rates, and ectoparasite loads.

Study species and study sites. Our study was conducted on a series of fringing reefs along the west coast of Barbados, West Indies (see map in Rakitin \& Kramer 1996). These reefs begin at the shoreline, with 'spurs' extending 100 to $150 \mathrm{~m}$ seaward before giving way to patch reefs and/oi scattered coral heads and rubble. The reefs are relatively eutrophic, and substratum at the shore end consists mostly of 'dead' reef, covered with filamentous algae and some macroalgae (Allard 1994). The proportion of live coral and sponge increases with distance from the shore.

At our sites, Microspathodon chrysurus are abundant (up to $0.04 \mathrm{~m}^{-2}$ ) from the reef crest seaward to the patch reefs just beyond the spurs, down to approximately $10 \mathrm{~m}$ depth. They are uncommon further from shore, in deeper water. We have observed them being cleaned by cleaner gobies Gobiosoma spp., juvenile bluehead wrasse Thalassoma bifasciatum, juvenile spanish hogfish Bodianus rufus, and the cleaner shrimps Periclemenes pedersoni and Stenopus hispidus.

\section{PILOT STUDY}

Methods. To determine if there was a relationship between habitat and cleaning activity, a team of 5 observers recorded activity budgets of fish at 2 sites (Greensleeves Reef and North Bellairs Reef) separated by $3.5 \mathrm{~km}$. Observations were conducted between 11 and 22 July, 1997 . We selected this period of the month because it coincides with the time of the lunar cycle when spawning activity in Microspathodon chrysurus is absent or low (Robertson et al. 1990), thus minimizing the potential effects of reproduction on cleaning. Each site was marked with 2 buoys indicating the shore-and seaward ends of the reef, and a third buoy approximately halfway between indicating the middle section. All observations were conducted from the surface by snorkeling. Each day, an observer recorded the behavior of 3 fish, 1 each from the shore end, seaward end, and middle section of the reef. The fish in each zone were selected haphazardly, except that males guarding eggs and neighbors of previously monitored fish were avoided. Territories were marked with flagging tape to facilitate relocation. The order of observations was determined randomly.

Observations of females at 1 of our sites revealed that time spent at cleaning stations peaked in the early morning and remained roughly constant but at a lower rate through the remainder of the day (P. Sikkel \& S. Herzlieb unpubl. data). Each fish was therefore observed for two $20 \mathrm{~min}$ periods, once in the morning 106:55 to 08:45 h) and once in the afternoon (14:15 to 15:45 h). At the end of the study period, observers measured the actual distance from shore and depth of each fish's territory. To avoid observer-site artifacts, each observer alternated sites each day she or he conducted observations. During focal observations, observers recorded the amount of time fish spent at cleaning stations, exhibiting the posture typical of fish soliciting or being cleaned by a cleaner. Such behavior is often called 'posing' (Losey 1971). Because cleaners were 


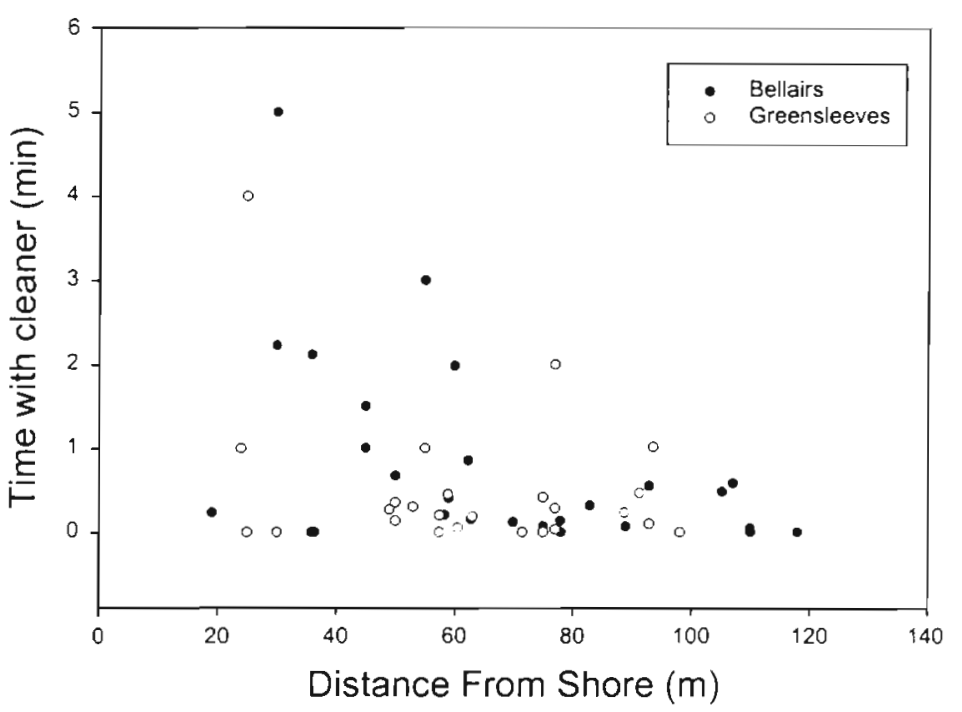

Fig. 1. Relationship between time spent with cleaners during $40 \mathrm{~min}$ of focal observation (sum of 20 min morning and afternoon observations) and distance from shore for aduIt Microspathodon chrysurus on 2 reefs. Observations were conducted in July 1997

collected and examined during that study. Crustacean parasites are eaten by the most common species of cleaner fishes at our sites (Rondall 1967, Losey 1974). We do not know if any of these, or other cleaners at our sites, eat monogeneans. However, monogeneans have been found in guts of cleaner wrasses Labroides dimidiatus from the Indo-Pacific (Grutter 1997). Based on these results, we conducted a more comprehensive study in 1998 to determine whether the relationship between time spent with cleaners and habitat (distance from the shore) was robust and whether fish closer to the shore had higher ectoparasite loads.

\section{Methods}

General. We conducted focal observations on and collected fish from 8 different fringing reefs between $26 \mathrm{May}$ and 13 June, 1998. The northern- and southernmost reefs were separated by approximately $3.8 \mathrm{~km}$. As with the

often associated with crevices and shelves, we could not always determine from the surface how long cleaners actually spent on posing fish. Observers also recorded incidents of chafing as another indicator of irritation. All fish were adults, but the sex of most of them was unknown.

Results. The distribution of the variables did not meet the assumptions of parametric analyses, even after transformation, and we therefore used non-parametric tests to compare time spent with cleaners with distance from shore. At both sites, time spent with cleaners was higher during the morning than the afternoon. Combining both sites, fish spent an average of $0.62 \mathrm{~min}(\mathrm{SD}=1.13$ ) with cleaners during the morning compared with 0.139 min ( $\mathrm{SD}=0.243$ ) during the afternoon ( $Z=2.95, \mathrm{p}=0.003, \mathrm{n}=61$, Wilcoxon test). This corresponds to 3.1 and $0.7 \%$ of their time, respectively. When data from the morning and afternoon were summed, both time with cleaners and chafing tended to decrease with distance from shore. The relationship was not significant for Greensleeves alone $\left(r_{\mathrm{s}}=-0.137\right.$, and $-0.189, p>0.20, n=25$ ), but was for North Bellairs $\left(r_{s}=-0.479\right.$, and -0.437 , respectively, $\left.\mathrm{p}<0.03, \mathrm{n}=27\right)$, and when data from both sites were pooled $\left(\mathrm{r}_{\mathrm{s}}=\right.$ -0.319 , and $-0.348, p<0.05, n=52$, Fig. 1).

\section{STUDY}

The pilot study revealed a decrease with distance from the shore in time spent with cleaners. We also found crustacean and monogenean parasites among 15 fish
1997 study, this time period coincided with the phase of the lunar cycle during which spawning is least active. We conducted focal observations on a total of 57 fish, and collected 67 for parasite analysis and determination of size and sex. A total of 49 fish were both observed and later collected. For 55 fish we also quantified the abundance of cleaner fish within the fish's territory. This allowed us to examine the possible effects of cleaner abundance on time spent with cleaners. Of the 67 fish collected, most (60) were examined for all categories of ectoparasites (see 'Quantification of parasite loads' section). The remaining 7 were not used for parasite analysis or were examined for only a subset of parasites.

Focal observations and cleaner density. Observations were conducted opportunistically between 07:45 and 09:45 hy a snorkeler who was also assisting divers with collection of fish (see 'Collection of fish' section), and lasted between 5.6 and $62 \min (\bar{x}=19.9, \mathrm{SD}=7.83)$. On each observation day, we observed 3 to 5 fish from either the shore- or seaward end of a reef. We then observed fish from the other end of the same reef on the following day. On each reef, the shore end and seaward locations were separated by approximately $100 \mathrm{~m}$. Depths ranged from 1 to $3 \mathrm{~m}$ at the shore end $(\bar{x}=1.9$, $\mathrm{SD}=0.67)$ and from 5 to $9 \mathrm{~m}(\bar{x}=6.85, \mathrm{SD}=1.14)$ at the seaward end. We selected fish haphazardly, subject to the constraint that we did not observe fish within $20 \mathrm{~m}$ of a fish that had already been observed.

We estimated the density of cleaner gobies, juvenile spanish hogfish, and juvenile bluehead wrasses for 55 fish by counting the number of each within a $6 \mathrm{~m}$ 
diameter of the capture location (see 'Collection of fish' section), or the fish's primary shelter hole (if the fish wasn't captured). Other types of cleaners were observed too infrequently to quantify.

Collection of fish. We collected Microspathodon chrysurus from the same reefs, during the same times, and using the same selection protocol as described above for focal observations. We collected each fish individually using a modified cast net. Immediately after capture, we placed the fish in a mesh bag and then placed the bag in a crevice in or near the fish's territory. After the last fish was captured for the morning, we collected all bags and transferred each fish to a separate bucket of seawater. Thus, fish remained in bags in or near their territory for up to $1 \mathrm{~h}$ after capture. After transferring fish, we placed each bucket in a shaded location on the deck of the boat and transported them to the laboratory. We then equipped each bucket with an aerator, placed it in a shaded location, and covered it with a dark cloth until the fish was examined for parasites. Thereafter, we measured each fish and examined gonads to determine sex.

Quantification of parasite loads. Our sampling protocol was designed to quantify the ectoparasites observed on fish in our preliminary study that were known or potential prey of cleaners. We also quantified the density of 3 species of monogenean parasite found on the gills. These parasites seem inaccessible to cleaners because they are found exclusively on the gill lamellae. The mouth and gill cavity of Microspathodon chrysurus is small and we never observed cleaners penetrating into their gill chamber. We thus did not include gill monogeneans in our analyses and do not present a description of our quantification technique below. In contrast, the crustaceans found in the gill chamber are highly mobile and not restricted to it (gnathiid isopods), or were found near the opening of the operculum (some copepods)

Crustaceans and cysts: We killed each fish immediately prior to examination for parasites by cutting through the brain and then pithing the spinal cord. This process took approximately $10 \mathrm{~s}$. Immediately after killing the fish, we placed it in a glass dissecting tray with seawater and examined its entire exterior surface, including the fins, under $10 \times$ magnification using a hand lens or dissecting scope. We then examined the mouth parts and gill chamber without magnification before removing the operculum and branchial basket. After the latter were removed, mouth parts, gill chamber, and opercula were re-examined without magnification, and the branchial basket was examined separately under a dissecting scope. After examination, the fish (all parts included) remained in the tray for $1 \mathrm{~h}$. We then examined the water from both the tray and the holding bucket for crustacean parasites that abandoned the fish during transport, holding, or pro-

Table 1. Summary of parasite loads for fish sampled at the shore and seaward ends of reefs. For gnathiids and copepods, load values represent the total numbers per fish. For monogeneans, values represent numbers per scale examined, per fish

\begin{tabular}{|c|c|c|c|c|c|c|c|}
\hline \multirow[t]{2}{*}{ Parasite } & \multirow{2}{*}{$\begin{array}{l}\text { Sex of } \\
\text { fish }\end{array}$} & \multirow[t]{2}{*}{$\mathrm{n}$} & \multicolumn{2}{|c|}{ Total length $(\mathrm{cm})$} & \multirow[t]{2}{*}{$\%$ infected } & \multicolumn{2}{|c|}{ Load } \\
\hline & & & Mean & $\mathrm{SE}$ & & Avg & Max. \\
\hline \multicolumn{8}{|l|}{ Shore end } \\
\hline \multirow[t]{3}{*}{ Gnathiids } & Female & 21 & 16.1 & 0.173 & 61.9 & 1.48 & 7 \\
\hline & Male & 7 & 16.1 & 0.141 & 57.1 & 1.14 & 4 \\
\hline & Subadult & 3 & 13.6 & 0.273 & 66.7 & 1.0 & 2 \\
\hline \multirow[t]{3}{*}{ Monogeneans } & Female & 21 & 16.1 & 0.173 & 57.1 & 0.014 & 0.054 \\
\hline & Male & 7 & 16.1 & 0.141 & 57.1 & 0.010 & 0.047 \\
\hline & Subadult & 3 & 13.6 & 0.273 & 66.7 & 0.013 & 0.025 \\
\hline \multirow[t]{3}{*}{ Copepods } & Female & 21 & 16.1 & 0.173 & 38.1 & 0.476 & 2 \\
\hline & Male & 7 & 16.1 & 0.141 & 29.6 & 0.286 & 1 \\
\hline & Subadult & 3 & 13.6 & 0.273 & 0 & 0 & 0 \\
\hline \multicolumn{8}{|l|}{ Seaward end } \\
\hline \multirow[t]{3}{*}{ Gnathiids } & Female & 8 & 15.6 & 0.338 & 37.5 & 1.0 & 4 \\
\hline & Male & 21 & 15.3 & 0.172 & 28.6 & 0.33 & 2 \\
\hline & Subadult & 0 & & & & & \\
\hline \multirow[t]{3}{*}{ Monogeneans } & Female & 8 & 15.6 & 0.338 & 50 & 0.006 & 00.17 \\
\hline & Male & 24 & 15.3 & 0.172 & 33.3 & 0.004 & 0.038 \\
\hline & Subadult & 0 & & & & & \\
\hline \multirow[t]{3}{*}{ Copepods } & Female & 8 & 15.6 & 0.388 & 50 & 0.750 & 2 \\
\hline & Males & 24 & 15.3 & 0.172 & 20.8 & 0.208 & 1 \\
\hline & Subadult & 0 & & & & & \\
\hline
\end{tabular}


cessing (see Grutter 1995b). If there was too much debris in the bucket (e.g. fecal matter) to allow us to see clearly, we poured its contents into a shallow pan and examined them. We preserved all crustaceans (whether known to be parasitic or not) in $70 \% \mathrm{EtOH}$ (ethyl alcohol) for identification and later measured the parasitic species ( $\mathrm{TL}$, excluding trailing egg masses).

Monogeneans: Our preliminary study revealed the presence of a species of monogenean attached to the scales of some fish. To quantify scale monogeneans, we removed scales from 1 side of the fish (we alternated sides between successive fish) and placed them in petri dishes of seawater taken from the fishes' bucket. Scales were removed in vertical rows. The posterior-most discernible row on the caudal peduncle and the scales posterior to it were counted as 1 row. Scales were removed from every fourth row on the peduncle, working from posterior to anterior, until we reached the anus ( 3 rows total), and then every third row on the body until we reached the head (preliminary work suggested that monogeneans were absent from the head). Rows included the dorsal and ventral margins of the fish if there were no fin rays at the ends of the row, otherwise the row ended at the fin. This procedure resulted in 10 rows of scales, and a mean of 159 ( $\mathrm{SD}=26.7$ ) scales examined per fish ( $n=63 \mathrm{fish}$ ). All scales with monogeneans attached were preserved in $4 \%$ buffered saline. We did not measure monogenean size.

Statistical analyses. We conducted analyses using SYSTAT 5.03 (Wilkinson 1990). We used parametric analyses when data met the assumptions, otherwise we used non-parametric tests. Because the ectoparasites found on Microspathodon chrysurus during this study (crustaceans or monogeneans) differed considerably in size and ecology, we analyzed each separately. Because body size may be correlated with parasite load (Grutter \& Poulin 1998, Lo et al. 1998) we included it in our analyses of cleaning and parasite loads. Only 5 fish had cysts, so we did not include these in the analyses of parasite loads.

\section{Results}

Sex and size of fish were not independent of habitat (Table 1). Among the 32 fish collected from the nearshore habitat, $4(12.5 \%)$ were immature. Among the 28 sexually mature fish collected from this habitat, 21 $(75 \%)$ were female. All fish $(\mathrm{n}=35)$ collected from the seaward end of reefs were sexually mature, and 27 $(77.14 \%)$ were male. The average size of fish collected from the nearshore habitat was also significantly larger $(\bar{x}=15.85 \mathrm{~cm} \mathrm{TL}, \mathrm{SD}=1.02)$ than that of fish collected from the seaward end $(\bar{x}=15.35, \mathrm{SD}=0.87, U=674$, $\mathrm{p}=0.014$, Mann-Whitney $U$-test). This strong association between habitat and sex makes it difficult to separate the relative contribution of each. Thus, we conducted analyses of activity budgets, cleaner density, and parasite loads using both as alternate independent variables.

Time with cleaners in relation to habitat and sex. Although fish were not observed for the same duration, duration of observation was not significantly related to the proportion of time spent with cleaners $\left(r_{\mathrm{s}}=-0.075\right.$, $\mathrm{p}>0.50$ ) and the latter was also unrelated to body size $\left(r_{s}=-0.039, p>0.50\right)$. Fish observed at the shore end of reefs ( $\mathrm{n}=30$ ) averaged a higher proportion of time with cleaners than fish at the corresponding seaward end $(n=27)$ at 6 of the 8 reefs. This difference was marginally non-significant $(Z=1.86, p=0.06$, Wilcoxon matched-pairs test), but there is a similar trend among reefs. Combined among reefs, fish at the shore end of reefs spent an average of $7.0 \%$ of their time (range $=0$ to $29.6 \%$ ) with cleaners, compared with $2.0 \%$ (range =
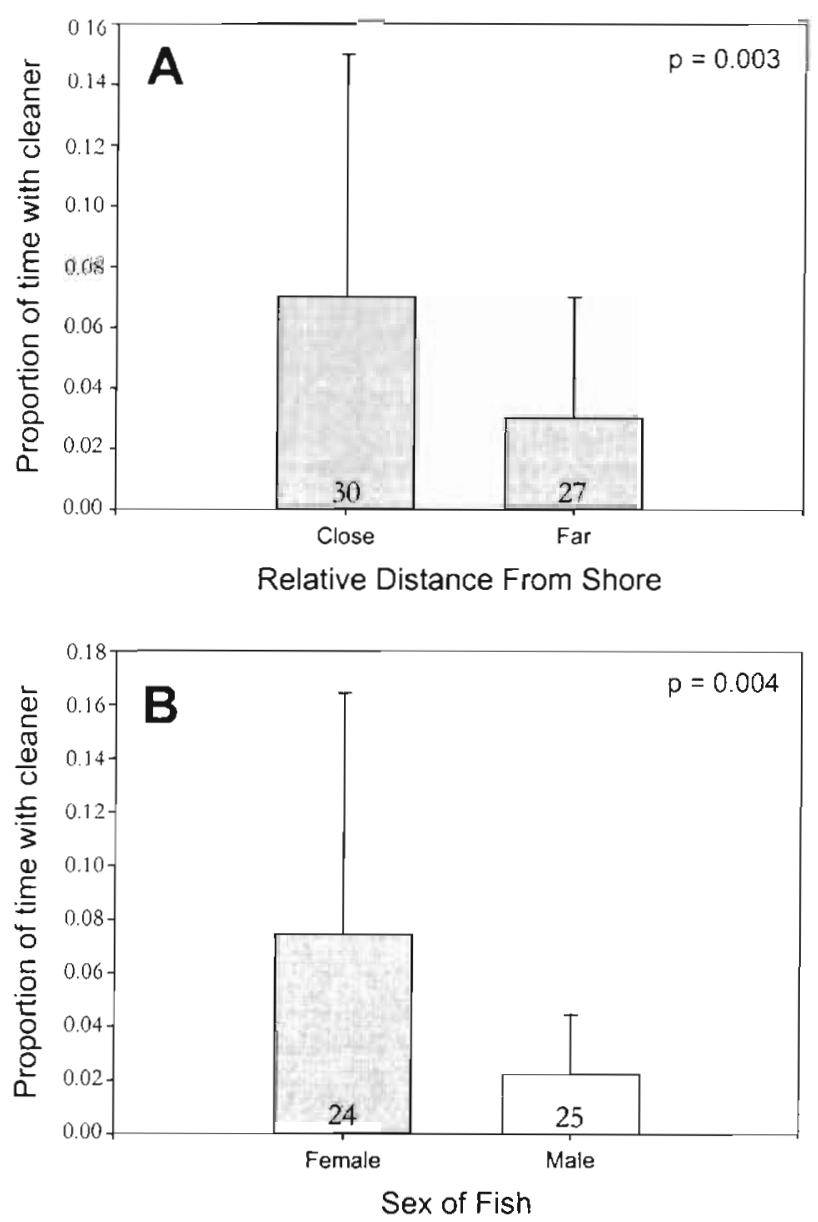

Fig. 2. Proportion of time spent with cleaners $(\bar{x} \pm S D)$ in relation to (A) habitat (reef zone) and (B) sex. Data are from morning focal observations conducted in 1998 
0 to $19.7 \%$ ) for fish at the seaward end. The overall difference is highly significant $(U=617.5, \mathrm{p}=0.001$, Mann-Whitney test, Fig. 2). For the 49 fish for which we knew the sex, females averaged a higher proportion of time with cleaners than males at 7 of the 8 reefs $(Z=1.96, p=0.05)$. For females combined, the average amount of time spent at cleaning stations was $7.4 \%$ $(\mathrm{n}=24$, range $=0$ to $29.6 \%$ ); for males it was $1.6 \%$ ( $\mathrm{n}=$ 25 , range $=0$ to $9.5 \%$ ). This difference was highly significant $(U=445.5, \mathrm{p}=0.003)$. Neither the effects of habitat nor sex were affected by the removal of data from the 3 males that had eggs in their nest $(p=0.012$ and 0.003 for sex and habitat, respectively).

Average chafing rates were higher in females than males at 6 of 8 reefs $(z=1.82, p=0.069)$. The overall difference was marginally non-significant ( $U=382, p=$ 0.097). The effect of habitat type on chafing was weaker, with average rates nearshore being higher for only 5 of 8 reefs, and no significant overall difference $(U=382, \mathrm{p}=0.708)$.

Abundance of cleaners in relation to habitat and sex. When grouped by habitat, the density of cleaner gobies and juvenile bluehead wrasses were both significantly higher for fish at the seaward end of reefs $(n=27)$ than the shore end $(n=28)(p<0.005$, Mann-Whitney test). When grouped by sex, densities of these species were higher near males $(n=26)$ than near females $(n=25)$ $(p<0.03)$. There was no significant difference in the density of juvenile spanish hogfish in the different habitats or near the different sexes ( $p=0.80$ and 0.13 , for habitat and sex, respectively).

Parasite loads in relation to habitat and sex. Crustaceans: The most common crustacean parasites were gnathiid isopod larvae (pranizae). These accounted for $71.25 \%$ of the parasitic crustaceans found on Microspathodon chrysurus. The remaining $28.75 \%$ consisted of parasitic copepods (Siphonostomatoida, Philichthyidae, and Bomolochidae). A summary of the distribution and relative abundance of crustacean parasites is presented in Table 1.

The large number of zero values for each parasite category precluded the use of parametric ANCOVA techniques to test for the effects of body size, sex, and habitat on isopod and copepod loads separately. We therefore used total crustacean load (gnathiid isopods + copepods) ( $\ln x+1$ transformed) as the dependent variable in a stepwise ANCOVA (SYSTAT MGLH) with body size (TL) entered first. An initial analysis revealed no site effect. We therefore pooled data among sites. Crustacean load was significantly related to body size $(p=0.001$, $r^{2}=0.16$; Fig. 3). When the effect of body size was removed, habitat ( $n=60$ fish) and sex ( $n=57$ sexually mature fish) were both significant when entered separately ( $\mathrm{p}=0.049$ and 0.036 , respectively). However, habitat was not significant when tested using only sexually mature fish ( $p=0.302$ ). Examination of residuals revealed that the regression of crustacean load on body size violated the assumption of homoscedasticity, even after transformation. This was because the low incidence of parasitism among the smallest fish resulted in relatively low variances near the origin. We therefore repeated the analysis after eliminating these data points (Fig. 3). When entered alone with body size, habitat type was not significant ( $p=0.476, n=48$ ). However, sex remained significant $(p=0.045)$. With the effects of body size statistically removed, average crustacean loads in females were approximately 3 times higher than in males

Parasitic copepods removed from fish were similar in length to gnathiid isopods $(t=0.745, p=0.46)$, and average length of crustacean parasites on fish was similar between sexes $(t=0.351, p=0.728)$ and among habitats $(t=0.285, p=0.770)$.

Monogeneans: Monogeneans (family Dactylogyridae) were found on scales of $47.6 \%$ of the fish examined (Table 1). In all cases, the worms were attached to the undersides of scales, never more than 1 worm per scale. Individual crustacean loads were not correlated with monogenean loads $\left(r_{s}=0.063, p>0.50, n=60\right)$. Fish with monogeneans attached to their scales were

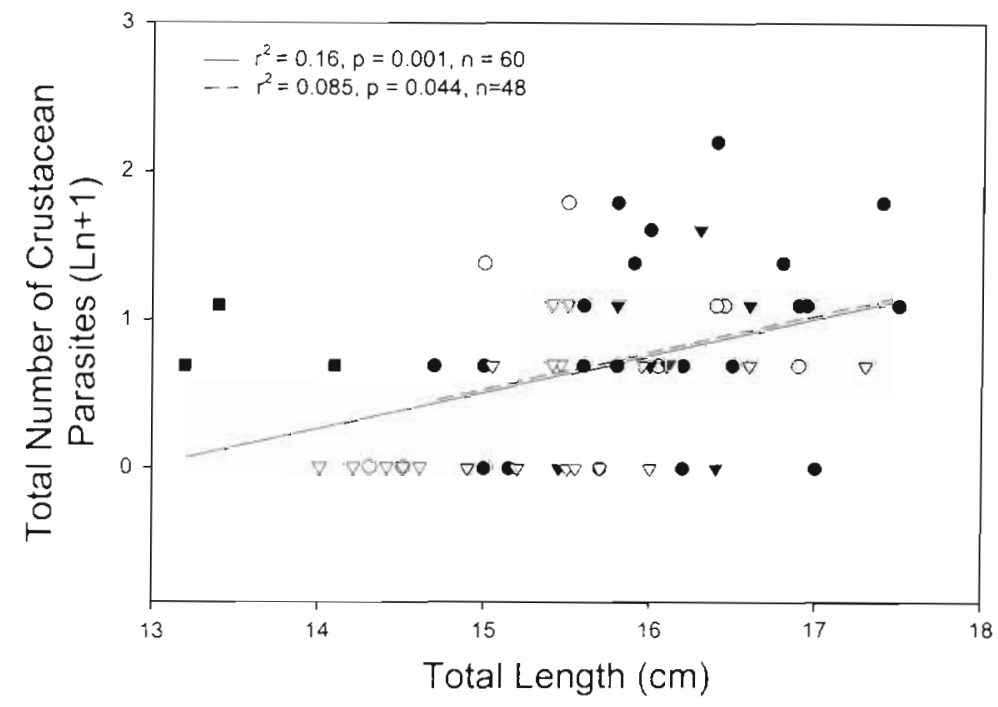

Fig. 3. Relationship between body size (TL) and total crustacean load (gnathiid isopods + copepods), showing deviation from least-squares bestfit by habitat and sex. Black symbols represent fish collected from the shore end of reefs, white symbols represent fish collected from the seaward end of reefs, circles represent females, triangles represent males, and squares represent subadults. Dashed line represents the regression for larger fish only $(>14.5 \mathrm{~cm})$ 
similar in size to those without $(t=0.437, p=0.663)$, and the number of worms per scale examined was not correlated with body size (TL) among infected fish ( $\mathrm{r}=$ $-0.204, p=0.279$ ). Females averaged more worms per scale than males, and fish at the shore end averaged more than fish at the seaward end at 6 of 8 reefs, suggesting a similar trend among reefs $(Z=1.53, p=0.125$, and $Z=1.42, \mathrm{p}=0.141$, respectively). However, overall differences were marginally non-significant $(p=0.07$ and 0.11 respectively, Mann-Whitney test). Nevertheless, because the loads of monogeneans on scales showed the same trend as crustacean loads, combined loads were still higher for fish at the shore end of reefs and/or females.

\section{DISCUSSION}

The strong association between sex and habitat (reef zone) makes it difficult to separate the relative contribution of each to parasite burden or time spent posing at cleaning stations. Still, as a population, fish that spent the most time at cleaning stations (females/fish in a female-dominated habitat) also had the highest parasite loads, even when the effects of body size were removed, and in spite of (or possibly because of) having fewer cleaners available to them. They also tended to have higher rates of chafing, an indication of irritation in fishes (Wyman \& Walters-Wyman 1985). These results appear consistent with predictions of adaptive, mutualistic hypotheses for client visitation to cleaning sites. Parasites may directly affect the tendency of Microspathodon chrysurus to seek out or remain in the presence of cleaners, or fish may adopt patterns of visitation to cleaners that reflect their average habitat or sex-specific parasite loads. Determining the direct effects of parasites on time spent at cleaning stations ultimately requires experimental manipulation of parasite loads. Such experiments are difficult to conduct in the field. Under laboratory conditions, Losey (1979) found a positive effect of parasite loads on time spent near a model of a cleaner in 1 of 2 species of Hawaiian reef fish. In a more recent laboratory study, Grutter (pers. comm.) found a positive effect of gnathiid isopods on time spent near a cleaner in the tropical pacific wrasse Hemigymnus melapterus. Losey (1974) noted the overall higher rates of posing for cleaners in Puerto Rico (Caribbean) relative to the tropical Pacific and suggested that this could reflect exposure to overall higher parasite loads over evolutionary time, rather than direct effects of the parasites themselves.

An alternative interpretation of our results is that time spent cleaning is unrelated to parasite loads, but habitat and/or sex-related differences in both may be the result of 1 or more common or unrelated factors that affect each independently. For example, lower availability of cleaners to females/fish near shore eliminates, as a possible alternative explanation for time spent with them, easier access to cleaners. However, lower cleaner density could result in increased time spent posing if fish sought a fixed amount of contact with cleaners, independent of parasite load. Fish may also be responding to other habitat-specific irritants correlated with parasite abundance. There are at least 3 alternative sources of irritation at our study sites that may be habitat-specific and could induce fish to visit cleaners. These include urchins, whose spine-tips we found imbedded under scales, localized concentrations of small stinging organisms such as siphonophores, and water quality. Of the 3 , the last appears most likely to show a decrease with distance from the shore, and to be able to contribute independently to levels of irritation and parasite loads. Most fringing reefs in Barbados receive runoff from agricultural and residential areas, and pollutants such as nitrates, particulates, and fecal coliform bacteria are highest near shore in areas dominated by females (Hunte et al. 1997). High levels of runoff also appear to be associated with outbreaks of protozoan infections, and the resulting eutrophic conditions may result in substrata that are favored by some ectoparasites. Determining the relative contribution of these factors to time spent posing for cleaners will require further comparative field studies, in addition to laboratory manipulation of parasite loads.

Few studies have attempted to quantify habitat variation in ectoparasite loads in tropical reef fishes, and we are not aware of any studies that have compared loads between sexes within species. Moreover, with rare exceptions (Grutter 1994, 1998) studies that have quantified habitat variation in ectoparasites have done so over large spatial scales (e.g. Yeo \& Spieler 1980, Rohde et al. 1994). Grutter (1998) found that monogeneans on a species of wrasse from the Great Barrier Reef were more abundant in the shallow reef flat habitat than in the adjacent, deeper reef slope. However, she found no difference in the abundance of gnathiid isopods. Understanding the factors that cause differences in parasite loads is essential not only for the understanding of cleaner-client interactions, but also because parasite abundance can influence habitat quality and habitat choice (Poulin \& Fitzgerald 1989). One difficulty is that parasite loads on reef fish at any given time are a function of the rate at which parasites infect fish, relative to the rate at which they are removed by cleaners or otherwise leave the host (Losey 1974, Grutter 1996). In our study, differences could be due to preferences of parasites for females, higher parasite abundance or encounter rates near shore/in female habitat, and/or higher rates of removal further 
from shore/in male habitat. The effects of greater abundance and a higher encounter rate appear most likely for parasites with a benthic life history stage. Gnathiid isopod larvae were the most common crustacean parasites on Microspathodon chrysurus at our sites. Adults are benthic but non-parasitic. Larvae alternate between parasitic (feeding on the blood of fishes) and benthic stages (e.g. Wäegele 1988). Many benthic zooplankters show habitat differences in abundance (Jacoby \& Greenwood 1988). It is therefore possible that territories vary in substratum favorable to gnathiids and that favorable substratum is more abundant closer to shore or in female territories. Alternatively, or in addition, fish closer to shore are also in shallower water and thus may, on average, experience a higher concentration of parasites. Similar local environmental factors could influence the distribution of monogeneans, including dactylogyrids, that also have a benthic phase (eggs that hatch into infective oncomiracidia) (Llewellyn 1972, Grutter 1998)

The fact that both cleaner gobies and juvenile bluehead wrasses were more abundant in male-dominated habitat suggests that higher removal rates are at least 1 factor contributing to habitat/sex differences in ectoparasite loads. Both have been reported, in other locations, to feed heavily on gnathiid isopod larvae (Randall 1967, Losey 1974), and we found gnathiids in the guts of cleaner gobies collected from 1 of our sites. Bluehead wrasses are also known to feed on parasitic copepods (Randall 1967, Losey 1974). We found up to 20 cleaners on individual coral heads and sponges in male-dominated habitat. This high density of cleaners probably contributes to the decrease in time spent at cleaning stations by males or fish farther from shore; a brief visit to a cleaning station can result in multiple cleaners removing parasites simultaneously. Quantitative studies of habitat effects of availability and consumption rates by cleaners will be required to resolve their relative contribution to parasite loads of Microspathodon chrysurus from these reefs.

Acknowledgements. Steve Herzlieb, Deborah Pakes, Ryan Chenery, Ramon Roach, Colette Wabnitz, and Sarah Fischer assisted with the behavioral observations. Ian Popple, Sarah Fischer and Fabian Rousset assisted with the collection of fish. They and Janina Skelton also assisted with quantification of parasite loads, and Jaime Morgan measured the parasitic crustaceans. Leon Duobinis-Gray identified the monogeneans and George Benz identified the parasitic crustaceans. We are grateful to all of them. We also thank Joan Marsden and the staff of the Bellairs Research Institute for logistic support, and Alexandra Grutter for comments on the manuscript, sharing her unpublished data, and directing us to the relevant Iiterature. Financial support was provided by a Bellairs Postdoctoral Fellowship to P.C.S., by an NSERC research grant to Donald Kramer, and by a MacArthur Foundation grant to W.H.

\section{LITERATURE CITED}

Allard P (1994) Changes in coral community structure in Barbados: effects of eutrophication and reduced grazing pressure. MSc thesis, McGill University, Montreal

Arnal C, Côté IM (1998) Interactions between cleaning gobies and territorial damselfish on coral reefs. Anim Behav 55: 1429-1442

Foster SA (1985) Wound healing: a possible role of cleaning stations. Copeia 1985:875-880

Gorlick DL (1984) Preference for ectoparasite-infected host fishes by the Hawaiian cleaning wrasse, Labroides phthirophagus (Labridae). Copeia 1984:758-762

Gorlick DL, Atkins PD, Losey GS (1987) Effect of cleaning by Labroides dimidiatus (Labridae) on an ectoparasite population infecting Pomacentrus vaiuli (Pomacentridae) at Enewetak Atoll. Copeia 1987:41-45

Grutter AS (1994) Spatial and temporal variations of the ectoparasites of seven coral reef fish from Lizard Island and Heron Island, Australia. Mar Ecol Prog Ser 115:21-30

Grutter AS (1995a) Relationship between cleaning rates and ectoparasite loads in coral reef fishes. Mar Ecol Prog Ser $118: 51-58$

Grutter AS (1995b) Comparison of methods for sampling ectoparasites from coral reef fishes. Mar Freshw Res 46 : $887-903$

Grutter AS (1996a) Parasite removal rates by the cleaner wrasse, Labroides dimidiatus. Mar Ecol Prog Ser 130:61-70

Grutter AS (1996b) Experimental demonstration of no effect by the cleaner wrasse Labroides dimidiatus (Cuvier and Valenciennes) on the host fish Pomacentrus moluccensis (Bleeker). J Exp Mar Biol Ecol 196:285-298

Grutter AS (1997) Spatiotemporal variation and feeding selectivity in the diet of the cleaner fish Labroides dimidiatus Copeia 1997:346-355

Grutter AS (1998) Habitat-related differences in the abundance of parasites from a coral reef fish: an indication of the movement patterns of Hemigymnus melapterus. J Fish Biol 53:49-57

Grutter AS, Poulin R (1998) Intraspecific and interspecific relationships between host size and the abundance of parasitic larval gnathiid isopods on coral reef fishes. Mar Ecol Prog Ser 164:263-271

Hunte W, Vermeer LA, Wiltshire H (1997) Environmental deterioration and marine water quality at fringing reefs on the west coast of Barbados. Technical Report for the InterAmerican Development Bank, Washington, DC

Itzkowitz $M$ (1977) Spatial organization of the Jamaican damselfish community. J Exp Mar Biol Ecol 28:217-242

Itzkowitz M (1979) The feeding strategies of a facultative cleaner fish. Thalassoma bifasciatum (Pisces: Labridae). J Zool (Lond) 187:403-413

Jacoby CA, Greenwood JG (1988) Spatial, temporal, and behavioral patterns in emergence of zooplankton in the lagoon of Heron Reef, Great Barrier Reef, Australia. Mar Biol 97:309-328

Johnson W, Ruben P (1988) Cleaning behavior of Bodianus rufus, Thalassoma bifasciatum, Gobiosoma evelynae, and Paraclimenes pedersoni, along a depth gradient at Salt River Submarine Canyon, St. Croix. Environ Biol Fish 23 $225-232$

Llewellyn J (1972). Behaviour of monogeneans. In: Canning EU. Wright CA (eds) Behavioral aspects of parasite transmission. Acadernic Press, London, p 19-30

Lo CM, Morand S, Galzin R (1998) Parasite diversity/host age and size relationship in three coral reef fishes from French Polynesia. Int J Parasitol 28:1695-1708 
Losey GS (1971) Communication between fishes in cleaning symbiosis. In: Cheng TC (ed) Aspects of the biology of symbioses. University Park Press, Baltimore, p 45-76

Losey GS (1974) Cleaning symbiosis in Puerto Rico with comparisons to the tropical Pacific. Copeia 1974:960-970

Losey GS (1979) Fish cleaning symbiosis: proximate causes of host behavior. Anim Behav 27:669-685

Losey GS (1987) Cleaning symbiosis. Symbiosis 4:229-258

Poulin R (1993) A cleaner perspective on cleaning symbioses: proximate and adaptive explanations. Bioscience 46: $512-517$

Poulin R, Fitzgerald GR (1989) Risk of parasitism and microhabitat selection in juvenile sticklebacks. Can J Zool 67: $14-18$

Poulin R, Grutter AS (1996) Cleaning symbioses: proximate and adaptive explanations. Bioscience 46:512-517

Rakitin A, Kramer DL (1996) Effect of a marine reserve on the distribution of coral reef fishes in Barbados. Mar Ecol Prog Ser 131:97-113

Randall JE (1967) Food habits of reef fishes of the West Indies. Studies Trop Oceanogr 5:665-847

Robertson DR, Petersen CW, Brawn JD (1990) Lunar reproductive cycles of benthic-brooding reef fishes: reflections of larval biology or adult biology? Ecol Monogr 60:311-329

Editorial responsibility: Otto Kinne (Editor),

Oldendorf/Luhe, Germany
Rohde K, Hayward C, Heap M, Gosper D (1994) A tropical assemblage of ectoparasites: gill and head parasites of Lethrinus miniatus (Teleostei, Lethrinidae). Int J Parasitol 24:1031-1053

Trivers RL (1971) The evolution of reciprocal altruism. Q Rev Biol 46:35-57

Wägele JW (1988) Aspects of the life-cycle of the Antarctic fish parasite Gnathia calva Vanhöfen (Crustacea: Isopoda). Polar Biol 8:287-291

Waldner RE, Robertson DR (1980) Patterns of habitat partitioning by eight species of territorial Caribbean damselfishes (Pisces: Pomacentridae). Bull Mar Sci 30:171-186

Wilkinson L (1990) SYSTAT: the system for statistics. SYSTAT Inc, Evanston, IL

Wyman RL, Walters-Wyman MF (1985) Chafing in fishes: occurrence, ontogeny, and evolution. Environ Biol Fish 12: $281-289$

Yeo SE, Spieler RE (1980) Habitat effects on the occurrence of parasites inhabiting the sergeant major, Abudefduf saxatilis (Linnaeus), with a list of parasites of Caribbean damselfishes. Bull Mar Sci 30:313-324

Youngbluth MJ (1968) Aspects of the ecology and ethology of the cleaning fish, Labroides phthirophagus Randall. Z Tierpsychol 25:915-932

Submitted: June 14, 1999; Accepted: September 21, 1999 Proofs received from author(s): February 14, 2000 